\title{
In memoriam Ann J. Woolcock. A star has been lost.
}

\author{
P. Macklem
}

A star has been lost. Ann Janet Woolcock died, too young, on February 17, 2001. The enduring friendship she and I shared has been a privilege that has enriched my life enormously. She was one of the few people whom I trusted absolutely. I miss her. She succumbed to a 15 year battle against breast cancer. For a long time almost nobody outside of her immediate family and her doctors knew about it. She insisted that it be kept a secret. She first felt the fatal breast lump in the fall of 1986 while she was at a meeting in Singapore. Because she needed to talk to someone and I was there, I knew from the very beginning and knew how much the news upset her. After returning to Australia she had a mastectomy, followed by chemotherapy because there were positive lymph nodes. There followed a period of relative quiescence when we all hoped that the dreaded disease had been conquered. Alas, in 1997, a lymph node biopsy showed a recurrence. Ann knew what the future held for her.

Rollo May has defined courage, not as the absence of fear, but as the ability to carry on in the face of despair. That fateful day in Singapore, I witnessed Ann's extraordinary courage for the first time. She was devastated by the uncertainty of her future. But to everybody else she acted as if everything was just fine thank you. There was not a clue that she might have received a death sentence. Following the recurrence in 1997 she continued to act as if nothing was wrong. She knew she would eventually lose the battle, but in the face of this despair, she carried on. She remained active in international affairs. She competed for and won a large grant for a Cooperative Research Centre. She motivated and organized her colleagues and developed the research programme for the CRC. A short time before her death her own personal research grant was renewed as were many others in the Institute for Respiratory Medicine that she founded. Talk about carrying on in the face of despair! She was a very courageous lady.

Ann's professional life was devoted to improving the care of patients with respiratory disease. Indeed, when she created the Institute for Respiratory Medicine her philosophy for it was to focus on research with important practical applications to improve diagnosis, treatment, management, and quality of life, particularly of asthmatics. She gathered around her a team of experts who could help her accomplish her goals. And accomplish them she did. She and her Institute became world leaders in the field of asthma research and

Correspondence: P. Macklem, Meakins-Christie Laboratories, McGill University, Montreal, Canada. management. She received many well-deserved national and international honours. Among others, she was an Officer of the Order of Australia and one of the few women members of the Australian Academy of Sciences.

To my mind, three of her achievements stand out above all others. In the early 1960s, before she came to work with me, her first research showed that asthmatics could have severe hyperinflation with loss of lung elastic recoil and that following appropriate therapy this could return to normal. These findings have been amply confirmed but never explained. How can the elastic properties of lungs which most of us regard as immutable, change so quickly? This remains as much a mystery today as it was when Ann first reported it. Secondly, Ann showed that normal subjects had a plateau on the dose response curve for smooth muscle agonists whereas in asthma this plateau was lost. For me and many others this is the fundamental abnormality in asthma. The plateau on the dose-response curve protects normal subjects against excessive bronchoconstriction. The loss of the plateau is the only way that asthma can become a serious illness.

She was, I believe, the first to develop individualized management plans for asthmatics. This is probably her greatest achievement and her idea has now been copied worldwide. It is probably the most important therapeutic advance for asthma since the introduction of steroids, and all it took was common sense, which Ann had in abundance.

My daughter Jennifer, an artist, who, as a child, knew Ann both in Montreal and later whilst an art student in Paris wrote "she was someone who had an enormous influence on me when I was little." I doubt

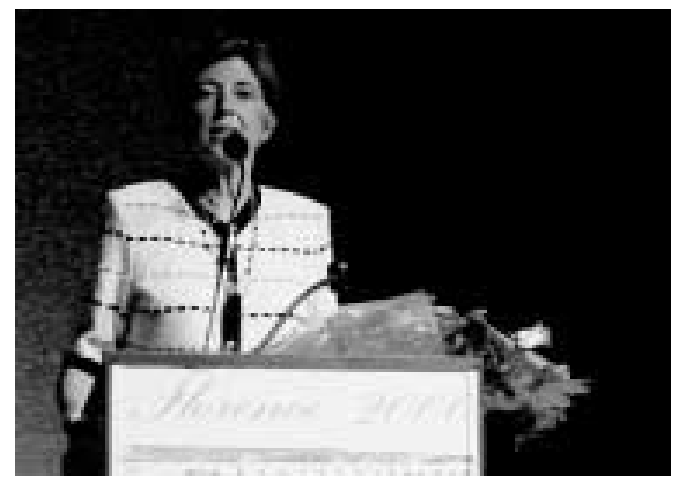

Fig. 1. - Ann receiving the presidential award at the ERS Congress Florence 2000. 
that Ann was aware of this, and I feel badly that she wasn't told. Her integrity, honesty, humility and generosity commanded more than respect. She was loved. During her last months she received more than 100 letters from around the world supporting her in her courageous fight. This profoundly touched her. Two and a half weeks before her death, Ann received an honorary degree from the University of Ferrara. During that celebration when I was with her for the last time I told her that all those letters showed how much she was loved. She appeared genuinely mystified. "Why should they love me" she said, "what have I done for them?" Ann, in her humility, only realized late in her life how much she was loved. Thank heavens she died with that knowledge. This love was so strong it was palpable during the two speeches she gave when she received her degree. She was not strong enough to stand and gave her talks seated with a weakened voice. She may have been physically weak, but she was mentally as tough as ever. Her courage, just to be there, was heart rending and she received two of the most emotional standing ovations I have ever witnessed.

Ann was a devoted wife and mother who had a close and loving relationship with her brothers and sister. Her family have suffered an irreplaceable loss. Our sympathies are with them. Her patients and indeed the worldwide community of asthmatics have lost their strongest advocate. Her colleagues in the Institute of Respiratory Medicine and in respiratory research the world over have lost an inspirational leader. The Meakins-Christie Laboratories has lost one of its most distinguished alumni. Ann was among my first research fellows and I have lost a scientific daughter. We have all lost a star. But the light she shed will not be extinguished. 